\title{
(conts \\ The textile industry and design strategies in the Meiji era Japan: \\ The case of the Nishimura Sozaemon family
}

\author{
Tomoko Hata / The Museum of Kyoto / Kyoto / Japan
}

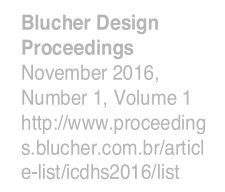

\begin{abstract}
At the time of the Meiji crisis, the Japanese textile industry had been utilising techniques derived from Western technology and promoting its export industry. Textile industry has played an important role in Japan's emergence onto the international stage as a major modern industrial power. Nishimura Sozaemon's family has a long history as a Japanese textile wholesaler and even now operate under the name Chiso Co. Ltd. It has exhibited artistic embroidery and yuzen-dyeing textiles both domestically and internationally. Nishimura Sozaemon combined textile products with the traditional Japanese paintings of Kishi Chikudo, Imao Keinen, and others. $\mathrm{He}$ aspired not only to promote the textile industry but also to demonstrate the high standards of Japanese textile quality as an art and to display Japanese pride on the world stage.
\end{abstract}

\section{Keywords}

Textile industry, embroidery and yuzen-dyeing on velvet, pictorial design, world's exhibition, government policy

\section{History before the Meiji era}

The Nishimura Sozaemon family founded a family business in the middle of the $16^{\text {th }}$ century. The family, in the Chikiriya clan, currently operates as a textile wholesaler under the name Chiso Co. Ltd., which is one of Japan's oldest businesses. According to the surviving genealogical records of the Nishimura family, the Chikiriya clan was founded during the Koji period (1555-1558) when Nishimura Yozaemon opened a shop selling clerical garments in the Sanjo-Muromachi district of Kyoto. The clan's shop flourished in the $17^{\text {th }}$ century, operating in more than 100 housing units. However, the only remaining direct descendants of the Chikiriya clan are the Nishimura Sozaemon, Nishimura Jihei, and Nishimura Kichisaemon families.

At several points in the long history of the Nishimura Sozaemon family, the family's future was in jeopardy. One such instance occurred towards the end of the Edo period in the early $19^{\text {th }}$ century when financial difficulties, compounded by troubles surrounding the family's inheritance, placed the family in a precarious situation. Nishimura Sozaemon IX sold the family estate in 1827 in order to pay back loans and went on to plan the family's restoration together with his 17-year-old sales clerk Ohashi Jusuke and two of his maidservants. Nishimura Sozaemon IX died one year later, whereupon the family adopted a three-year-old child from the Chikiriya clan that they raised to become the tenth Nishimura Sozaemon. The young Ohashi Jusuke, a mere employee, raised his infant master and resuscitated the family business with the support of the clan. Despite Nishimura Sozaemon X dying at a young age, Ohashi Jusuke, now head clerk, managed to lead the business to success and bought back the family's estate. In recognition of his achievements, he was named the $11^{\text {th }}$ Nishimura Sozaemon.

In the year 1873 (Meiji 6), Mikuni Naoatsu of the Mikuni family was adopted into the Nishimura family and became the $12^{\text {th }}$ Nishimura Sozaemon. The modernisation policies and Westernisation ideologies of the new Meiji government brought significant changes to the industrial structure in place at the time. Up until the Edo period, the textile industry in Kyoto had mainly produced vestments for use in temples and shrines and personal attire for the Daimyo and court nobles. Starting in the Meiji period, however, this market rapidly declined due to the removal of the Emperor and court nobles to Tokyo as well as the catastrophic damage to temples caused by the antiBuddhist movement. The Nishimura Sozaemon family, who until the Edo period had mostly supplied the Higashi Honganji temple, started to seek new business overseas from the Meiji era onward. 


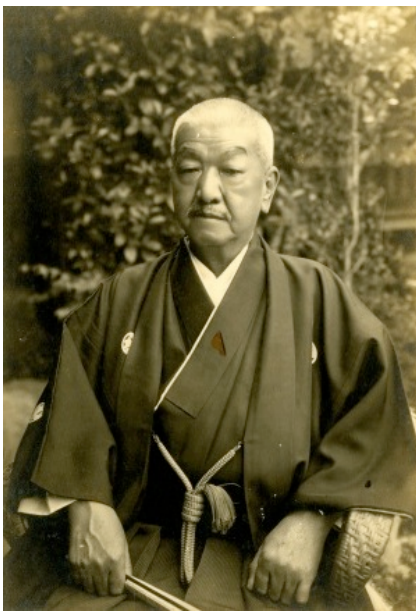

Fig. 1: Nishimura Sozaemon XII. Mikuni Naoatsu, late $19^{\text {th }}$ Century, Chiso Co.Ltd.

\section{Reconstruction of the textile industry in Kyoto}

December 1870 (Meiji 3), the Meiji government set up an establishment for promoting industry called the Seimi-kyoku Bureau in the Nijo-Kawaramachi district of Kyoto. The name Seimi was coined by transcribing the German word chemie (chemistry) using Chinese characters. Foreign specialists were invited there as lecturers with the aim of furthering industrialisation, especially in the field of chemistry. Incoming Western knowledge of chemical dyes and their uses was taught at the establishment. Moreover, during the 1873 (Meiji 6) international exposition held in Vienna, three textile workers from Nishijin, Kyoto, and toured Europe with government exposition officials, stopping in Lyon, France, to learn weaving techniques. They returned home with Jacquard and Battant looms, bringing about revolutionary

progress to Kyoto's textile technologies. After that, the government began dispatching Japanese workers to France and Germany to learn dyeing techniques. Foreign artisans and Japanese workers who studied abroad became lecturers and imparted their knowledge to many more workers, resulting in vast improvements in production quality as well as quantity.

On the other hand, Japanese arts and crafts such as ceramics, cloisonné ware, metalwork, and embroidery were highly regarded in the early days of the international exposition. This was because of the fact that Japan's handicrafts were extraordinarily elaborate, as well as because of the influence of 'Japonism' (Japanese influence mainly by Ukiyo-e (woodcut prints and crafts)). The Japanese government ranked the country's handicrafts as a major export product and implemented measures to improve design quality. Designs that would increase foreign interest in Japan came to be sought after.

\section{Influence of Mikuni Yumin}

Mikuni Naoatsu was adopted into the Nishimura family in the year 1873 (Meiji 6). The year was a turning point for Japan's economy and industry, and it was from then on that the Meiji government actively pursued ways to increase

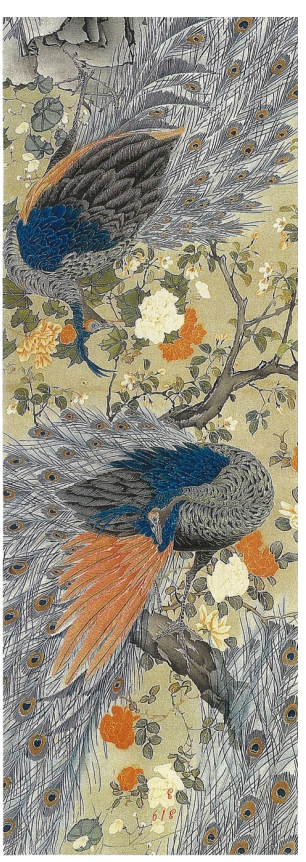

Fig. 3: Yuzen-dyeing piece. Illustrated by Kishi Chikudo, 1874, Chiso Co.Ltd.

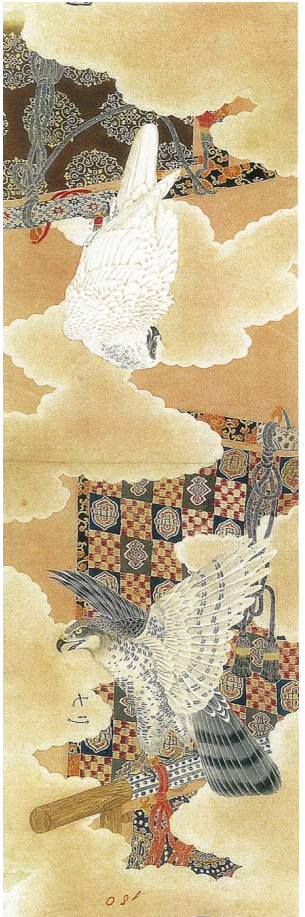

Fig. 4: Yuzen-dyeing piece. Illustrated by Imao Keinen, 1891, Chiso Co.Ltd. production and promote industry and exports.

Now the $12^{\text {th }}$ Nishimura Sozaemon, Mikuni Naoatsu succeeded in incorporating Japanese styles of painting into embroidery and yuzendyeing. His connections with Japanese painters were made through his father, Mikuni Yumin. Mikuni Yumin was a sinologist and scholar of Kangaku, which is the study of the classical ideologies and literature of China. He was born in Fukui and immigrated to Kyoto in 1832 at the age of 23. His family were merchants who ran a marine transport business in Fukui's Mikuni Harbour, which was an excellent environment for acquiring new information and knowledge from overseas. In Kyoto, Mikuni Yumin became the jukan (official Confucian teacher) of the Takatsukasa family (court nobles), and he came into contact with many scholars and artists. The study of Kangaku was essential not only for the court nobility and intellectual class but also for painters, since they were often required to produce paintings about Chinese legends.

Early artists who interacted with Mikuni Yumin and were involved with the textile business of the Nishimura family include Kishi Chikudo and Imao Keinen. Kishi Chikudo, originally from Hikone in Shiga Prefecture, was heir to the Kishi School developed originally by Ganku. He specialized in shasei, a style of painting characterised by realistic depiction. He provided original drawings not only for the embroidery 
and textiles of the Nishimura Sozaemon family but also for those of other textile manufacturers such as Tanaka Rishichi. However, we can infer that Chikudo's ties to Mikuni Yumin and the Nishimura family were particularly strong from the fact that his last paintings are in the possession of the Nishimura family, as well as the fact that he worked on the sliding doors of the Higashi Honganji temple (a temple with which, until the Edo period, the Nishimura family held strong ties).

Imao Keinen began his artistic training as Suzuki Hyakunen's apprentice, but, in his youth, he had also studied Kangaku under Mikuni Yumin. Keinen provided numerous sketches to the Nishimura family, and we can deduce that he and the family held strong ties from the fact that in the year 1891 (Meiji 24), he published a collection of Kacho-ga (paintings of flowers and birds) through the Nishimura Sozaemon establishment.

\section{Renovation by Nishimura XII}

The key characteristics of the revolutionary work of Nishimura Sozaemon XII in the Meiji period are as follows:

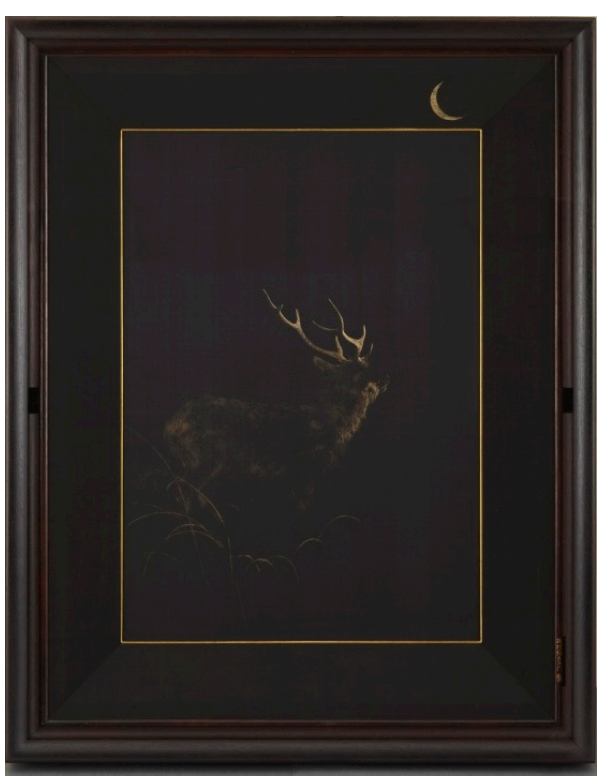

Fig. 5: Embroidery by Nishimura Sozaemon XII. Late $19^{\text {th }}$ Century, Kyoto prefecture

1. He integrated Japanese paintings into embroidery and yuzen-dyeing.

2. He disseminated the techniques for yuzen-dyeing on velvet.

That being said, these accomplishments were not Nishimura's alone; in part, they were the result of the handiwork and design capabilities of the Kyoto textile industry's workers. Nishimura held a role more akin to that of a producer, creating sublime works of art by employing talented textile workers.

Let us follow the works produced by Nishimura Sozaemon and the exhibitions in which they were displayed. At the international exposition that took place in the early years of the Meiji period, his displayed works comprised many items that, up until then, had been intended for domestic sale, such as fukusa (small cloth wrappers) and tablecloths. However, in the second domestic industrial exposition held in the year 1881 (Meiji 14), his piece Kujaku (peacock) was displayed. This is a $172 \mathrm{~cm}$ piece of embroidered shioze (Japanese silk) dyed with yuzen. The sketch of the peacock is based on a painting by Ganku, which is still in the possession of the Nishimura family. The piece is widely regarded for its fine embroidery, so diligently woven and exquisite that one could mistake the picture for the real thing. In the fourth domestic industrial exposition, the embroidered piece Kannon (a figure of the Deity of Mercy) was displayed and won first prize. The original picture was the work Yoryu Kannon (Kannon with a Willow Twig in a Vase), hanging in Daitokuji temple and copied by Kishi Chikudo for the design. These large-scale pieces of embroidery were framed or put on scroll mounts so as to be appreciated as works of art.

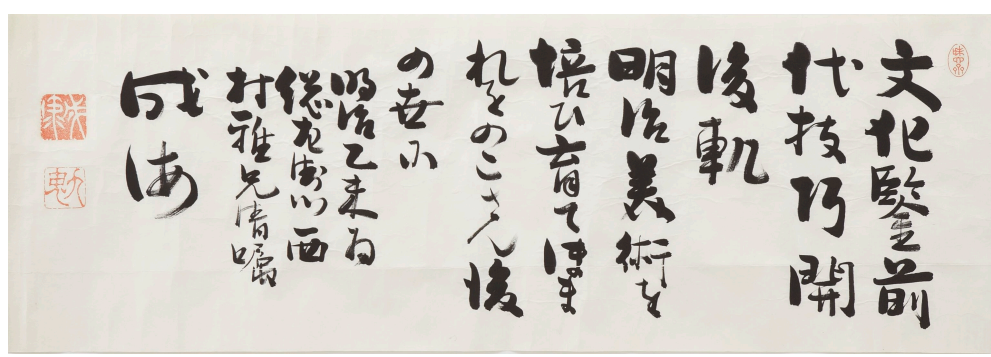

Fig. 6: Calligraphy by Kuki Ryuichi. Chiso Co.Ltd., 1895

The phrase 'yuzen-dyeing on velvet' could be used to characterise the major elements of the second domestic industrial exposition of 1881 (Meiji 14). The first velvets woven in Japan in the $17^{\text {th }}$ century were plain and unsuited to the dyeing of designs and patterns. The Nishimura family developed the technique of dyeing weft threads containing copper wires, thereby succeeding in reproducing fine Japanese paintings on velvet. They displayed these pieces at the 1900 Paris international exposition and the 1904 Saint Louis international exposition, where they received high praise.

These dyed and woven textiles - pieces of clothing and interior fixtures embellished with Japanese paintings using new techniques and refined sketches - are pieces of art of which Japan should be proud and which greatly contributed to its progress in the textile industry. 


\section{References}

A History of Chiso- 460 years of Tradition and Inovation (2015) Kyoto, The Museum of Kyoto \& Chiso Co. Ltd.

Hiroko T McDermott \& Clare Pollard (2012), Threads of Silk and Gold, Ornamental Textile from Meiji Japan, The Ashmolean Museum, Oxford

Mikuni Ikkaku, Waraigusa, (1896) private publishing

History of Mikuni-cho, (1964).Mikuni-cho

Murakami Bunga, History of Modern Yuzen-dyeing (1927), Unsodo

Kuroda Yuzuru, Records of Visiting Kyoto families (1899), Goshishoho

\section{Biographical note}

Dr. Tomoko Hata is the curator of the Museum of Kyoto. 